\title{
Four-dimensional conversion for spiritual leadership development: A missiological approach for African churches
}

\begin{tabular}{|c|c|}
\hline \multicolumn{2}{|c|}{$\begin{array}{l}\text { Authors: } \\
\text { Kalemba Mwambazambi }{ }^{1} \\
\text { Albert K. Banza }{ }^{2}\end{array}$} \\
\hline \multicolumn{2}{|c|}{$\begin{array}{l}\text { Affiliations: } \\
{ }^{1} \text { Department of Practical } \\
\text { Theology and Missiology, } \\
\text { University of Stellenbosch, } \\
\text { South Africa }\end{array}$} \\
\hline \multicolumn{2}{|c|}{${ }^{2}$ Independent scholar } \\
\hline \multicolumn{2}{|c|}{$\begin{array}{l}\text { Correspondence to: } \\
\text { Kalemba Mwambazambi }\end{array}$} \\
\hline \multicolumn{2}{|c|}{$\begin{array}{l}\text { Email: } \\
\text { profkalemba@yahoo.fr }\end{array}$} \\
\hline \multicolumn{2}{|c|}{$\begin{array}{l}\text { Postal address: } \\
\text { Private Bag X1, Matieland } \\
7602 \text {, South Africa }\end{array}$} \\
\hline \multicolumn{2}{|c|}{$\begin{array}{l}\text { Dates: } \\
\text { Received: } 11 \text { Mar. } 2013 \\
\text { Accepted: } 08 \text { July } 2013 \\
\text { Published: } 14 \text { Apr. } 2014\end{array}$} \\
\hline \multicolumn{2}{|c|}{$\begin{array}{l}\text { How to cite this article: } \\
\text { Mwambazambi, K. \& Banza, } \\
\text { A.K., 2014, 'Four-dimensional } \\
\text { conversion for spiritual } \\
\text { leadership development: } \\
\text { A missiological approach } \\
\text { for African churches', } \\
\text { HTS Teologiese Studies/ } \\
\text { Theological Studies 70(3), } \\
\text { Art. \#1953, } 9 \text { pages. http:// } \\
\text { dx.doi.org/10.4102/hts. } \\
\text { v70i3.1953 }\end{array}$} \\
\hline \multicolumn{2}{|c|}{$\begin{array}{l}\text { Copyright: } \\
\text { (C) 2014. The Authors. } \\
\text { Licensee: AOSIS } \\
\text { OpenJournals. This work } \\
\text { is licensed under the } \\
\text { Creative Commons } \\
\text { Attribution License. }\end{array}$} \\
\hline \multicolumn{2}{|l|}{ Read online: } \\
\hline arda & $\begin{array}{l}\text { Scan this QR } \\
\text { code with your } \\
\text { smart phone or } \\
\text { mobile device } \\
\text { to read online. }\end{array}$ \\
\hline
\end{tabular}

The process of a four-dimensional conversion and/or transformation strives in helping the leadership of an organisation, especially such as the church, with practical ways that may lead to the development of an effective leadership by observing the four important aspects of human spirituality as elaborated on in the article. The spiritual, intellectual, moral and socio-political dimensions of the transformation can be catered for so that the complete inner being of humans, as well as their social and political attitudes and behaviours, can equally be transformed to maximum spiritual, personal and socio-political profitability. MutomboMukendi demonstrates that the need for a spiritual leadership that can contribute to an effective transformation of Africa is dire, both for the church and the larger community. The real challenge is how to develop such leadership. This article provides intentional and practical ways that may lead to the development of the needed leadership. Four-dimensional transformation of people can be planned and carried out both in the church arena and in the surrounding communities. Skills development and transfer can also take place when skilled people from the church work with unskilled people from the community.

\section{Introduction}

The African continent is currently suffering from a predominantly poor leadership that is generally characterised by negative traits such as fraud, injustice, tribalism, immorality, xenophobia, corruption, selfishness, hatred and exploitation of the underdog. All these negatives are undergirded by poor and confused spirituality at the individual and societal levels. Unfortunately, many Christians are counted amongst African people who are not spiritual and who commit many spiritual and socio-political misdeeds. 1 Corinthians 3:1-4 and Hebrews 5:1214 show that the problem of Christians who are carnal and not spiritual goes back as far as to the beginning of the Church in the 1st century. As the situation continues to be so, Mihai (2009:1) observes, '[s]ome people are religious without being spiritual, while others are spiritual without being religious'. Yet, many church people and their leaders confuse the concept of spirituality and religion or even religiosity; consequently, they equally confuse spiritual leadership with religious leadership. Wellman, Perkins and Wellman (2009) insist that the two differ from each other:

While some may feel uneasy about using words such as 'spirituality' and 'spiritual' when discussing workplace values, it is important to remember that 'spiritual' and 'religious' are not synonymous. [They posit that] 'spirituality' is not defined by an explicit set of religious beliefs or practices. On the contrary, spirituality does not need religion at all to define itself. ... Spirituality, therefore, is more about how people identify themselves, how they view the world interact with others, and make decisions. (p. 1)

Examining some leaders of the past who were not spiritual, Mihai (2009) concludes that:

$[t]$ hey not only lacked honour, compassion, and responsibility towards others, but as fear-based leaders, they were also known for destruction and lack of respect for [humankind] in general. By contrast, a spiritual leader in today's workplace would be fundamentally different and would demonstrate different qualities and behaviours in their daily interactions with others: Encourage and inspire employees to find meaning and purpose in their lives. Demonstrate empathy. Show integrity, honesty, kindness, and respect in dealing with others. Value the well-being of others above their own interests. Live by example, encourage creativity and learning. Be socially and environmentally responsible. Be ethical and moral. Have a certain degree of humbleness and aim to serve and inspire others. Promote leadership based on respect and love, not fear .... (p. 1)

Wellman, Perkins and Wellman (2009) suggest that:

leadership theorists posit that spirituality is the core of effective leadership that guides behaviors and interactions with others. Thus, an effective leadership model will include characteristics of being scholarly, practical, ethical, moral, just, caring, equitable, fair, and democratic. (p. 1-2) 
Spirituality includes three subcategories: caring for others, transcendence and seeking goodness, truth and forgiveness. Churches and other religions need spiritual leadership as much as all human communities and organisations do.

However, as suggested by Kalemba (2011:1), the Church of God that is supposed to play the role of the light of the world and salt of the earth (Mt 5:13-16), should take responsibility for helping people to become effective light and real salt in their communities by developing spiritual leaders both for the church and for the larger community. The lack of such leadership affects individuals and communities negatively. This challenge is glorious as it can bring the Church of God back to its 'Great Commission' of making disciples of all nations, teaching them to observe all that the Master, Jesus Christ, taught (Mt 28:18-20). Kalemba (2011:12) rightfully stipulates, '[t]he Church is called to deal with spiritual and moral formation and take up the responsibility of developing effective leaders in the community'.

Analytic and descriptive methods have been used to study and explain key notions. The usefulness of spiritual leadership, causes of lack of such leadership, and how to develop this important leadership have been examined and described. The development of this leadership can be effected through a chain of activities ranging from family life, the community in which one lived, school, college and university attended, but this articled has chosen church activities, especially as carried out through the use of a fourdimensional conversion and/or transformation. The details of the process of a four-dimensional conversion have been explained in practical terms.

The development of this spiritual leadership required the use of what Kä Mäna (2000:78) calls New Evangelism in Africa, or else what Kalemba (2011:2) calls In-depth Evangelism, where moral leadership principles and formation can be offered. These two scholars have used New Evangelism or In-depth Evangelism without explaining what this would look like or how it would operate. The article has especially interpreted these notions and given them more practical meaning in an integrated form of evangelism and a discipleship process called socio-political discipleship, which leads to a four-dimensional conversion. Explaining transformation theology, Phan (1996) speaks of a multiple conversion, which Banza (2013:303-319) has detailed as socio-political discipleship for a four-dimensional conversion. A process of a multiple conversion has been used to thus reach a deep transformation, which can lead to the development of spiritual people who can become effective spiritual leaders. The main research question of this article is: How can the African Church and its leaders contribute to the development of a spiritual leadership in the larger community?

\section{Process of four-dimensional conversion}

This process proposes the four dimensions of conversion which African churches can follow in their discipleship in order to develop strong, mature and spiritual Christians who would also become spiritual leaders in their communities. The process can also be used whilst working with the surrounding communities to nurture Christians and community people into persons who can contribute effectively to sociopolitical transformation. Leaders thus developed can also be Christians capable of living as dignified citizens of the kingdom of God in the human community and can also become efficient church leaders. This process encompasses the development of people fit for the dignified public service to the community, who can equally be the salt of the earth and light of the world, as suggested by Mutombo-Mukendi (2011:163). Mostert (2007:149) advocates that the development of such people is better because it focuses on the human value as essential for socio-political transformation rather than other methods which ignore nurturing self-leaders, who are the right people for transformation. Hauerwas (1995:42, 46-47) equally advises the development of people who can be responsible Christians in their being, behaving and living with others. African churches need to be socio-politically transformational and proactive to be an appropriate context where a transformational leadership of the Church can effectively use a four-dimensional discipleship for the needed leadership for socio-political transformation.

Knowledge of the African context, scholarly experiences of researchers and those of church workers and inspiration from the Bible have supported the use of a socio-political intercession, which can always go with a socio-political evangelism as part of the process of four-dimensional conversion. Prince (2000:56) supports the idea of sociopolitical intercession as indicated in 2 Chronicles 7:14, that people of God have first to humble themselves, confess their sins, turn from their wicked works and seek God's face before they can see God healing their land. Commenting on 1 Timothy 2:1-2, Hagin (1996:2) insists that instant prayers, supplications, intercessions and thanksgivings be primarily done for everyone, especially for kings and for those people who are in authority. Here, God requests Christians to intercede because he desires their partnership to see many others can be saved and come to knowledge of the Truth. Intercessions for everyone, for socio-political leadership and even for church leadership can go along with the knowledge and fear of God; they can also precede, accompany and follow up evangelisation and discipleship to maximise the transformation of individuals and communities. Such intercession constitutes an effective socio-political intercession that lends a powerful helping hand to both people involved and the work they are doing. Evangelism and a socio-political discipleship that go along with this intercession aim at the transformation and development of spiritual leaders who can effect socio-political transformation in their community.

A process of a four-dimensional conversion aims at progressively integrating head knowledge of the Bible - a passive knowledge that can be integrated progressively through this process of four-dimension conversion - into the actual day-to-day living to develop the needed character in 
humans for socio-political transformation (Barna 2001:90-93). Jehoshaphat's project in Judah which brought about deep spiritual, economic, social and political transformation can be of special inspiration to African churches. Being a godfearing king, to disseminate the fear of God in the whole kingdom, Jehoshaphat sent his leaders, Levites and priests to teach the fear of God to his people (2 Chr 17:7-12). This resulted in a nation well taught about the true love of God, able to effectively serve him and their own neighbour, which further resulted in an extensive peace within and around Judah, huge riches and considerable respect by the surrounding kingdoms that brought abundant presents to the kingdom of Judah. African church leaders can make it their special business of making true disciples of Jesus Christ, people who really know him and fear him, as suggested by Katongole (2011:46-47), love other people and enjoy serving them, and practise mercy and justice (Mi 6:8; Mt 28:19-20).

This process is also essential for the empowerment of Christians. Speaking of power, empowerment and cultural acquiescence, Edet (1994:124) maintains, '[t]heologically, every Christian is empowered by Jesus at his or her Christian initiation to function fully as a child of God'. He further adds, 'Christ empowered all who turned to Him ...' (Edet 1994:125). Nowadays, Jesus still empowers all those who turn to him to develop a real character of Christ in them in order to lead a life worthy of Christ's glory. The deeper and more balanced the conversion is, the more spiritually strong a Christian becomes. The more holistically spiritual, psychologically and socio-politically healthy a church leader is, the fitter she or he will be able to contribute to the transformation of others, and consequently to that of their community.

Dorr (1990:8) and Phan (1996:114) point out that there as to be a full conversion in order for someone to enjoy a better relationship with God and with one's neighbour, both in word and in deed. A full conversion means one which affects these different dimensions of personal and spiritual, interpersonal and socio-political life. Banza (2013:308) terms the four dimensions of this conversion as religious, intellectual, moral and socio-political. Exodus 35:30-35 and Exodus 36:1 speak of the God of Israel, who called Bazalel, the son of Uri and filled him with the Spirit of God, in wisdom and understanding, in knowledge and all manner of workmanship, to design artistic works. Then God appointed him and Aholiab, the son of Ahisamach to do the work of the sanctuary of God. The inference from these Scriptures is that God is the origin and the provider of skills and careers. The submission of the skills and careers to God's authority can ascertain their maximal use and proper management. Therefore, when skilled people, people who have expertise and careers, are encouraged within the process of fourdimensional-conversion to contribute with their skills and careers to the development of leadership and to sociopolitical transformation, much better results can be reached.

Conversely, when natural gifts, skills, careers and social positions are not submitted to God's authority, it can lead to privatised faith, and dualistic and anti-social behaviours developing easily in believers' lives. Encouraging discipleship for socio-political transformation, McDowell and Beliles (2008:190-195) suggest that community people can be educated and prepared to effect transformation in their communities. Therefore, an intentional effort can be made through the process of the four dimensions, to allow the integration of the development of people's skills and careers and use these for socio-political transformation to take place. The integration of personal skills and/or careers within personal spirituality plays an important role in combating dualism, anti-social attitudes and actions and privatisation of faith in day-to-day living. As individual formal and informal skills and/or occupations are included, it equally allows the gaining and development of more insights for practical transformational leadership on the part of both church leadership and membership. Community people can also be educated for personal and socio-political transformation. The process of socio-political transformation can start with the dimension of religious conversion at the personal level.

\section{Religious conversion}

In religious terms this conversion is important, as it plays an integrating role for an individual to be identified as an effective member of his or her religion. It is sometimes termed 'spiritual conversion'. Marsh (1990:235) describes it, stating, ' $r$ religious conversion is the peak of self-transcendence'. Then, on the same page, he continues saying, '... religious conversion is other-worldly falling in love with God without restriction'. This falling in love takes place when one receives Jesus Christ as personal Lord and Saviour. This is basically the unmerited reception of the grace of God which brings an entirely new dimension of divine presence into human life, according to Miller (1999:23).

The conversion opens the person to all of God's richest resources, as stated in Ephesians 1:5. The verse indicates that Christians have been blessed with all blessings in the heavenly places. A lot of African church members and their leadership claim to have experienced this conversion, though many of them still worship various other gods, as indicated by Kä Mäna (2000:34-36), and lack godly love and ethics, according to Mutombo-Mukendi (2005:120-122), who explains that this is due to the lack of proper Christian education. Given its spiritual use, church leaders should make sure they know the nature and level of their members' faith through observation, spiritual dialogue and questioning methods to be able to take the next step for their proper spiritual growth. If proven, the process can be followed through so as to bring their faith to a higher level through prayer, adequate Christian education and the practice of the Word of God. Asking church members whether they accepted Jesus Christ as personal Lord and Saviour and being sure this really happen can help for the way forward.

Kä Mäna (2001:34-36) dubs African Christianity as being largely a constant juxtaposition of African traditional religions and Christianity. He says that many of those Christians claim to believe in Jesus Christ as their saviour, protector 
and provider. At the same time they widely practise many other religious beliefs. This practice of different religious belief systems leads to a dangerous and generalised spiritual mediocrity, spiritual irresponsibility and unclear conscience in their lives. Their condition is ultimately comparable to that of the people of Samaria reported in 2 Kings 17:24-34, where social disasters were constantly looming. Such Christians thus end up being ruined by lives of lies, duplicity, confusion, hypocrisy and a high sense of irresponsibility, creating a situation where one can hardly know which god will bless them. Believing that any form of Christianity can contribute to the development of an ethical leadership elsewhere in Africa is utopian and irresponsible. True and sincere spiritual conversion based on personal intuitive, illuminative or revelatory experiences of God, which engage someone into a God-initiated process of becoming like Christ, as suggested by Kretzschmar (2006:344-345), can play a decisive role in solving such problems. Maxwell (2007:viii) suggests Christlikeness as an essential criterion for the selection of church workers. It is also a major requirement for the choice of effective spiritual church leaders. The fact that Christlikeness is such a qualifying or disqualifying condition shows how important religious conversion is for Christian living, and consequently for transformational church leadership, because no one can become Christlike without accepting Christ as personal Lord and Saviour in his or her life (Kretzschmar 2006:344-345).

At the same time church leaders can allow the development of a sense of prophetic theology and boldness in Christians so that they can always be prepared to stand for things which are to God's glory and for the good of many. Bible passages such as Daniel 3:19-30 and 6:1-28 can be shared, being interpreted in the context of the 'disguised' African dictatorship. The first passage relates how Daniel's three friends resisted King Nebuchadnezzar's order to serve his god and how God honoured their faith by protecting them and demanding all peoples to regard Shadrach, Meshach and Abednego's God with respect. The second elaborates on how Daniel worked in a political and dictatorial environment, fearing his God and doing his work ethically. It is also about Daniel's refusal to violate his prayer covenant with God and how God honoured his faith to the extent that everyone in the kingdom was obliged to respect Daniel's God. African Christians and church leaders who are afraid to speak and act against their domineering political leadership and those who conform their lives to unethical standards of society can be exhorted to behave and live according to their religion's recommendations. Exhortations about God's spiritual, physical, social and professional protection against attacks from evil powers can also be conveyed to afford the spiritual growth of Christians to total stability so as to avoid them recourse to satanic protection.

Church leaders can also encourage church members to know how they can make their skills and/or careers part of their Christian being and living and how they can use them. They can know, for example, how to speak of their faith and touch others by acts of living faith so that they can be brought to spiritual conversion. Another key dimension is intellectual conversion as developed below.

\section{Intellectual conversion}

This conversion involves the transformation of someone's natural thinking and the acquisition of a godly philosophy through certain behaviours and actions, which can also affect the thinking, being and life of the person. Smith (1981:179) defines intellectual conversion as 'radical clarification and, consequently the elimination of an exceedingly stubborn and misleading myth concerning reality, objectivity and knowledge'. Romans 12:2 indicates that the change of mind causes transformation, prevents conformity to worldly life and allows discerning what the good and perfect will of God is. This is to say that this conversion helps one to acquire God's perspective and distinguish right from wrong in order to come to effective observation of God's will, practice of love for the neighbour and for the community at large.

Intellectual conversion is very important for all Christians to reach the necessary change in mind-set; but it is even more important for the leading African people to help them see life from God's perspective and to understand and use the power they have according to godly principles; that is, for their own good, for that of their communities, and for the glory of God. Intellectual conversion is of special importance for prominent African people, who generally appreciate life according to the thinking of the common people and their own selfish needs and ambitions, and not according to godly principles. The development of this conversion requires intentional and constant actions from church leaders and missiologists and from Christians who need transformation. Church leaders can thus teach, exhort, intercede, and organise intercession for that purpose and follow everything through. Taking this advice into consideration, these new Christians can read, meditate, study and, where necessary, memorise sections or verses of the Bible and pray for the purpose. They can also learn special Scriptures according to their particular skills, careers or occupations in order to be able to protect and defend their faith and/or to use that faith for the spiritual and socio-political good of many. Practically, they also contribute to the development of this conversion by connecting any socio-cultural or political event in the community with a Bible text in order to help them know the reasons why what is good is to be done and what is wrong is to be avoided.

Though Christians have the privilege of benefitting from the help of the power of the Holy Spirit, it can equally be noted that people who are not Christians can also reach intellectual conversion, but in a different way. In this case it is generally called intellectual transformation. Bible stories can be shared and characters used to stir people up to positive actions for the benefits of many voiceless, weak or powerless people. 1 Samuel 17:45-47 tells of a young man who, because of the love of his God and his people, decided to lay down his life. It showcases a highly-skilled David fighting an experienced warrior Goliath to defend God's people, who 
were unable to defend themselves. Esther 4:13-17 and 5-8 speak of a young queen who risked her life for the good of her people; they bespeak of the express reason why and the responsibility queen Esther had to shoulder as a queen at the precise moment. The Bible, as well as any other insightful and seminal literature, can be used to this effect. The primary objective of organisations such as TMALI (Thabo Mbeki African Leadership Institute) is this conversion, but in a different perspective. The organisation intends to provide a different perspective of Africa and Africans and of how to bring about transformation in the continent to the people they train through specific activities and knowledge. The next dimension in the process of transformation might be a conversion to others, especially to the poor and to all those people socio-politically or spiritually in any kind of need - a moral conversion.

\section{Moral conversion}

This is a conversion chiefly concerned with one's interpersonal relationships. Dorr (1990:13) explains that moral conversion is more than mere preparedness to observe moral principles. It is a deeper change of heart and/or mind, making one readily prepared to relate to others, especially, to the poor, on a person-to-person basis. To be morally converted is to have come to the point where one can 'see as really significant the events that touch the lives of the poor, for better or for worse' (Dorr 1990:17). Paying careful attention to the underdogs or to any persons in a material or any other need, listening compassionately to them in order to assist them, are signs of moral conversion. Caring for them in any way and even praying for their needs to be met as did Peter and John in Acts 3:1-8 are also expressions of moral conversion.

This conversion consists in helping people clearly discern the good to do and evil to avoid, and empowering them with the needed ethical character for the proper actions, attitudes and behaviours. Moral conversion is very important for everybody; but it is more important for Christians to show love to humanity. It is even more important for Africans, who have lost their original sense of ubuntu and acquired transactional relationships, to redevelop and deepen and enhance relationships with others. Proper development of people's moral conversion can offer the church transformed and spiritual Christians, the community transformed citizenry, and NEPAD (New Partnership for Africa's Development) and the African Renaissance the kind of people they need in order to work adequately and succeed, according to the pledge in NEPAD (2001:57). This conversion is not exclusively something religious. When Pityana (1999:137) speaks of moral renewal, he is basically referring to this conversion. Similarly, Teffo's description $(1999: 166,168)$ of moral rebirth amounts well to this conversion. Of course, these two scholars speak from their own fields of knowledge, which contribute to spiritual, moral and social advancement.

Ubuntu, which Pityana (1999:144) considers as the organising principle of African morality and 'reference to human solidarity', as well as relevant Biblical principles coupled with appropriate examples provided by church leaders, community leaders, parents or any other people of influence an easily help develop this conversion. Visits to and caring for the elderly and needy, for example, can play a very important role for such a development. Through wellplanned discipleship, developed in combination with moral and spiritual formation, and caring actions to people in need, good results can be achieved. The integration of moral and spiritual formation with wider aspects of church education and a nurturing role, as well as the shaping of the life of African Christians after the model of Jesus Christ can well lead to much better results.

The neglect or ignorance of the development of this conversion in the church does not seem to be an African problem only. Speaking of the long-lasting counterproductive results due to the lack of moral-philosophical development amongst American evangelicals, Charles (2002) observes:

the relative inattention to winning a person's mind and way of thinking, an inattention that tends to depreciate a long-term strategy of building relationships and addressing moral-philosophical complexities, has lasting results that are counterproductive to evangelicals' mission to the world. (p. 226)

To avoid these long-lasting counterproductive consequences and prepare for Africans readily prepared for effective transformation, Africans and the leaders in their church and community can consequently work for intensive moral persuasion. Church members can also play an important role in this connection, according to their spiritual growth, careers or skills and social standing. They can be encouraged to individually or collectively do what they can to positively affect the life of someone in a certain need or that of their community. The fourth conversion is therefore about the development of the necessary socio-political values.

\section{Political conversion}

Political conversion can also be called socio-political conversion. According to Miller (1999:132), this conversion and other dimensions of moral and intellectual conversion are very important for the socio-political transformation of African communities. Explaining this conversion, Dorr (1990:14-15) says that political conversion is the conversion of one's mind to political responsibility. To be politically converted involves the understanding of how one's society is structured and how it works, and the commitment to correcting injustices, not only on an ad hoc basis, but also by replacing the unjust structures with equitable ones. Training and developing people who can do such work or who can contribute effectively to the needed transformation is a qualifying factor. Miller's (1999:132) discussion on forms of conversion provides three other terms, which describe types or dimensions of conversion that can also be accommodated here.

Commenting on Conn's contribution, he suggests a different but complementary form of conversion that also deals with the appropriation of feelings: affective conversion. 
This conversion is considered a transformation of desire: a turning from possessive desire to a desire for generosity; it is a reorientation from the possessiveness rooted in obsessive concern for one's own needs to the self-giving of intimate love and generative care of others (Miller 1999:132). Then, discussing what he calls socio-political conversion, Miller (1999:133) takes on an affective conversion. The affectively converted take responsibility for the health of their emotional growth. Affective conversion is then complemented by intellectual, moral, and religious conversion; but all four types express personal responsibility for decisions. Ultimately, he recommends a fifth form, that of socio-political conversion. The socio-politically converted people take responsibility within the limits of a realistic possibility for influencing the decisions of others, especially, for influencing the decisions that give shape to large, impersonal institutions that influence human life and experience.

This fifth dimension is deemed essential to de-individualise the notion of conversion, forcing engagement and dialogue with the values of the collective beyond oneself, 'The Others,' as he puts it. This aspect of conversion demands personal dedication to a reasonable cause which seeks to affect the common good. The affective conversion with its turning from the obsessive concern for one's own needs to the selfgiving of intimate love and generative care of others as well as the socio-political conversion discussed above, with its forcing engagement and dialogue with the values of the collective beyond oneself, represent a great similarity with political conversion to be accommodated in it. The common denominator is their interest in the good of the other, in common good and in socio-political transformation.

This conversion is of greater importance for everybody to be able to combat political irresponsibility and positively contribute to social justice and a proper transformation of the community. Analysing leading Africans' psychology and what undergirds their wrong socio-political attitudes, behaviours and actions, Banza (2003:45-48) demonstrates that there are glaring cases of political irresponsibility amongst them. Indifference towards their nations or communities suffering from poor leadership, for example, or from unjust wars, economic and socio-political exploitation are some of the signs of the lack of this conversion. Conversely, transcending the mere talks about or listening passively to talks about victimised nations or communities to take an initiative and/or an action for the happy resolution of such unfortunate situations as listed above, are signs of political conversion in the life of someone. Prevailing prayer for the development of good leadership or for the sociopolitical transformation of a community is also a good sign. Combatting this irresponsibility in order to develop in people a heart for their own good and that of their community is also a Christian responsibility for church workers as well as a socio-political responsibility for all.

Developing a deep sense of African traditional ubuntu, where possible, is equally part of this responsibility. This ubuntu is expected to be a really globalising version, free from tribal, ethnic, nationalistic or religious limitations that can harm relationships with people from other tribes or groupings and religions, as can be seen in the description of Maggy from Maison Shalom. Describing Maggy's vision for a 'new' Burundi, Katongole (2011:175, 176) observes that Maggy came to see her mission as one of healing the Burundi society. She expected Maison Shalom, which is the name of her organisation, to become not simply an example of the identity and calling of God's love, but also the seed for a new culture and indeed a new future founded on the story of love. She worked to see Burundi give birth to a new generation of people who would carry the light of love and forgiveness to all the surrounding hills of the country.

\section{Describing ubuntu, Teffo (1999) observes:}

[u]buntu or humanness implies a basic respect for human nature as a whole. It is a social ethic, a unifying vision enshrined in the Zulu maxim 'Umuntu ngumuntu ngabanye' (One is a person through others). (p. 153)

What can also be inspiring from this statement is that, as a philosophy, ubuntu is a unifying vision for the communal welfare. It is like one of the Biblical principles: 'Love your neighbour as yourself' (Mt 22:39). The use of relevant Biblical principles such as the 'golden rule' in Matthew 7:12 and many others, and of the philosophy of ubuntu, compounded with good and appropriate living examples, can well help the development of this conversion to fruition. Telling Africans stories of their fellow-citizens who were motivated to fight for the benefit of all and who chose to sacrifice a lot, even to death, such as Patrice E. Lumumba of the Democratic Republic of Congo, can also make a difference. Gordon (2002:74-75) explains how this Congo-loving leader determinedly worked for the unity of the country, for total independence of his land and for future social justice, despite countless death threats. Such stories told by knowledgeable and disinterested leaders can inspire many and develop in them a strong sense of socio-political transformation.

Regarding the transformation of individuals and communities as essential, Ramasamy (2004:107) makes a few proposals in order to relate theories and appropriate actions. Suggesting how Christian principles and ubuntu can positively contribute to transformation in Africa, he proposes that the gospel value of human solidarity that recognises the importance of all human beings - who are therefore deserving of compassion and justice regardless of tribal, ethnic or cultural allegiances - be associated with an effective living out of ubuntu. The gospel must be used to liberate women from oppression, a practice that is often grounded in culture. If the African Renaissance stands for the liberation of the African people, then this is one of the chief areas of enslavement with which it must deal. Practising unconditional love and accepting everybody despite human differences constitute the answer to the many instances of hatred and conflict that afflict the continent. This is critical, especially, with regard to the ethnic tensions that are so prevalent in the continent. True love is to love one's enemies (Mt 5:44-46). This love, agape, a very powerful Christian 
value, is unconditional and reaches out to anyone, regardless of the race or ethnic group to which they belong. Jesus goes beyond a mere ethic of duty and makes love and compassion the motivating factor.

This is clearly demonstrated in the parable of the Good Samaritan, where the Jewish religious leaders remained indifferent to the needs of the dying man. It was the Samaritan, someone from the despised group, who enacted a ministry of compassion that saved the victim. This is what ubuntu is all about - a sense of identifying the needs of others as members of a common humanity (Ramasamy 2004:107-109). In this way, Christian conversion could help to gradually reconstruct the social fabric of divided and unjust societies such as the Congolese, Great Lakes and other African social fabrics for the benefit of all.

Restoring $u b u n t u$ by developing a strong sense of political conversion in African churches would create a strong and harmonious sense of community in which unconditional love can be expressed in practical terms. It would also recognise the worth of the individual. African churches being the ekklesia of God, and it will reflect within their structures and theology both the need for community and worth of the individual. European colonialism, in partnership with Protestantism, promoted an individualistic ethic that disrupted the fundamental communal pattern of African social existence. The original pattern of Judaeo-Christian society was a corporate one. There is a need to restore this order, as it harmonises closely with the African spirit of ubuntu. In this way the church can prove to possess a model that can advance the cause of the African Renaissance. In the New Testament one finds the corporate idea of koinonia, fellowship, into which God has called us. The church is thus more than an institution that promotes ritualistic activities and church programmes, but rather it is a fellowship with all the implications of caring amongst members. The virtue of communalism which involves a high degree of sharing and mutual responsibility would then be restored. African traditional societies were characterised by a relative economic equality, as communal solidarity prevented self-enrichment on the part of individuals, as indicated by Nthamburi and Waruta (1997:52).

The early church was characterised also by the redistribution of resources, and thus developed a strong sense of community (Ac 2:44-47). Ubuntu can therefore create the context in which the value of love can flourish. It makes for a caring that strives to ensure the wellbeing of fellow citizens. Indifference to the needs of the poor and refusal to share one's possessions with them means a lack of love for the neighbour and a lack of the sense of social justice, which further means that one certainly cannot claim to be compassionate. Christian ethics is concerned with the many political, social and cultural issues that confront society. Amongst these challenges are the problems of globalisation and poverty which the African Renaissance is striving to overcome. We consider the need for Christians to return to the Torah and the Prophets who stood for the poor, the weak and the oppressed, as essential here. This ethics is essential, especially when it goes beyond the process of reflection and analysis to involve commitment on the part of Christians locally and globally. The Christian message shall then be both proclaimed and practised to be real. In this instance African churches can engage in poverty alleviation programmes as well as criticism of economic policies (such as neo-liberalism, globalisation) that tend to favour the rich and powerful nations whilst impoverishing the weaker nations, without selfish ambitions or fear of the powerful (Ramasamy 2004:107-109).

A practical contribution to political conversion can consist in asking Christians to look around them and uncover a problem for which they or the church can provide a solution, using the available skills, careers or occupations. So acting would lead to more creativity in order to solve practical socio-political problems of their community and help the surrounding people to see the relevance of the church in their midst. Such Christians can hardly become selfish or exploitative leaders if ever they are given the opportunity to lead in some capacity. Conversely, they would aptly ready themselves for servant leadership.

Proposing a framework of the development of an African leadership to African Renaissance leaders, Van Rensburg (2007) equally recommends psychological restoration for an effective development of an African leadership free of common negatives known in the lives of African leaders. He then declares:

Several African writers are of the opinion that a characteristic of the African people is their benign docility. This characteristic made them easy prey for exploitation. Overwhelmed and probably disillusioned, many Africans in the post-colonial era reverted to blackmailing and fraudulent practices as means of improving their personal conditions. It is evident that Africa's people are in need of messages that will give them hope and self-belief as Africans. It is one victory to get rid of the claims of imperialists rule, but another to find the self-confidence needed for success in a world where one so easily can be left behind, or outside. (Van Rensburg 2007:61-62)

In this connection we can suggest that, whilst dealing with spiritual issues, African churches can equally deal with educational, socio-political and developmental issues proper for effective leadership and socio-political transformation. People who have special skills and / or are in professions which can contribute to the development of political conversion and/or skills in others and/or socio-political transformation in the community can be encouraged to use their expertise and careers where necessary for the needed transformation. Following on that, the educational recommendations as suggested below can be of real transformational value. Hoppers, Moja and Mda (1999:233) suggest that, when dealing with the development of people who have lost their self-esteem, their pride as well as their dignity, it is important that the 'knowledge' fed to them, be fused with a sense and objective of helping them regain that which they have lost. This overhaul can begin with a reinstitution of an explicitly people-centred conception of development, a development 
of a sense of commitment and loyalty to the development of the 'whole' human being (spiritual, mental, social, as well as other aspects, such as economy and so forth). An emphasis on a collective development rather than an individualistic accumulation of wealth, and a conscious learning from constructive African philosophies and the putting of that wisdom to overt use are essential (Mida 1999:233).

\section{Conclusion}

Sub-Saharan Africans who claim to be Christians constitute a majority (Banda 2010:109); so it is essential that African churches nurture spiritual Africans who can be candidates for effective socio-political leadership. Unfortunately, Adeyemo (2006:1303) observes that African Christians seriously lack spiritual depth because of poor Christian education and adaptation. The process of four-dimensional transformation has proposed how this education and adaptation can be improved so that the influence of spiritual people nurtured from the African churches can also contribute to an increased spiritual leadership that can impact on effective transformation in the continent. Spiritual Christians can serve their God as the Holy One, both in the church arenas and in the larger community in a dignified manner. The article has equally laid an emphasis on collaboration with the members of the communities where African churches operate, in order to sensitise them so that they can work together for the comprehensive and sustainable development of a transformational political leadership. Churches and their leadership have also to pray for the transformation of people and communities. They should also intercede for current church and socio-political leaders to be continuously transformed socio-politically. Such socio-political intercession is used for God, who is able to turn the hearts of leaders wherever he wishes (Pr 21:1) and who can uplift or put leaders down as he wills (Dn 4:35-36) to do the work in them.

The article has made different suggestions on how to develop the necessary character in people and the community. Basically, instead of looking for transformational leaders the community has never groomed, African churches and the larger community leaders can design and execute training programmes that can help develop the desired characters within the population of the community according to the needs. The various dimensions of conversion are geared so as to combat specific socio-political evils and develop particular characters in people.

Inconclusion, acting consistently for the deeper transformation of individuals and socio-political transformation of the community, African churches will prove themselves real multicultural, transformational, holistic and globalising instruments of transformation that can make real social difference both spiritually and socio-politically.

\section{Acknowledgements Competing interests}

The authors declare that they have no financial or personal relationship(s) that may have inappropriately influenced them in writing this article.

\section{Authors' contributions}

K.M. (University of Stellenbosch) was the project leader, and A.K.B. (Independent scholar) made conceptual contributions.

\section{References}

Adeyemo, K. (ed.) 2006, Africa Bible commentary, Word Alive Publishers, Nairobi.

Banda, Z.J., 2010, 'African Renaissance and missiology: A perspective from mission praxis', DTh thesis, UNISA, Pretoria.

Banza, K., 2003, 'Empowering African elites for Christian praxis: The experience of the International Church of Pretoria', master's thesis, UNISA, Pretoria.

Banza, K., 2013, 'Transforming Africa: The role of the church in developing political leaders', DTh thesis, UNISA, Pretoria.

Barna, G., 2001, Growing true disciples: New strategies for producing genuine followers of Christ, WaterBrooks Press, Colorado Springs.

Charles, J.D., 2002, The unformed conscience of evangelism: recovering the church's moral vision, InterVarsity Press, Downers Grove.

Dorr, D., 1990, Spirituality and justice, Orbis Books, New York.

Edet, R.N., 1994, 'Power, empowerment and cultural acquiescence', in S. Mailema (ed.), Theological reflection, culture, religion and liberation, pp. 117-128, Penrose Book Printers, Pretoria.

Gordon, J.U., 2002, African leadership in the twentieth century: An enduring experiment in democracy, University Press of America, Lanham.

Hagin, K.E., 1996, The interceding Christian, Kenneth Hagin Ministries, Tulsa.

Hauerwas, S., 1995, In good company: The church as polis, University of Notre Dame Press, Notre Dame.

Hoppers, C.A.O., Moja, T. \& Mda, T., 1999, 'Making this our last passive moment: The way forward', in M.W. Makgoba (ed.), African Renaissance: The new struggle, pp 233-239, Mafube \& Tafelberg, Cape Town.

Kalemba, M., 2011, 'The church task regarding leadership crisis in sub-Saharan Africa', paper presented at Africa Leadership Forum, Nairobi, Kenya, 04-11th November.

Kä Mäna, 2000, La nouvelle évangélisation en Afrique, Karthala and Clé, Paris and Yaounde.

Kä Mäna, 2001, Le souffre pharaonique de Jésus Christ, Sherpa, Yaoundé.

Katongole, E., 2011, The sacrifice of Africa: A political theology for Africa, Wm. B. Eerdmans Publishing Co, Grand Rapids.

Kretzschmar, L., 2006, 'The indispensability of spiritual formation for Christian leaders', Missionalia 34(2/3) 338-361.

Marsh, J.L., 1990, 'Praxis and ultimate reality: Intellectual, moral, and religious conversion as radical political conversion', Ultimate Reality and Meaning 13(3), 222-240.

Maxwell, J.C., 2007, The Maxwell leadership Bible: lessons in leadership from the word of God, Thomas Nelson, Nashville.

McDowelL, S. \& Belilies, M., 2008, Liberating the nations: Biblical principles of government, education, economics and politics, Provence Foundation, Charlotteville.

Mihai, J., 2009, 'Spirituality and leadership. Would an organization benefit from spiritual leaders?', Spirituality in Higher Education Newsletter 1(4), 1-2.

Miller, M.C., 1999, Abraham Kuyper. Living ethics unique, Peter Lang Publishing, New York.

Mostert, B., 2007, The Power of intercession, Carpe Diem Media, Vanderbijlpark.

Mutombo-Mukendi, F., 2005, Du mirage nationaliste à l'utopie-en-action du messie collectif, L’Harmattan, Paris.

Mutombo-Mukendi, F., 2011, La théologie politique africaine: exégèse et histoire, L’Harmattan, Paris.

New Partnership for Africa's Development (NEPAD), 2001, Abuja.

Nthamburi, Z. \& Waruta, D., 1997, 'Biblical hermeneutics in African instituted churches', in H.W. Kinoti \& J.M. Wiliggo (eds.), The Bible in African Christianity, pp. 40-57, Acton Publishers, Nairobi.

Phan, P.C., 1996, 'Contemporary theology and enculturation in the United States', in W. Cenkner (ed.), The multicultural church, pp. 109-130, Paulist Press, New York. 
Pityana, N.B., 1999, 'The renewal of African moral values', in M.W. Makgoba (ed.), African Renaissance: The new struggle, pp. 137-148, Mafube \& Tafelberg, Cape African

Prince, D., 2000, Comment façonner l'histoire par la prière et le jeune: comment les chrétiens peuvent influencer le cours des événements mondiaux par le moyen simple et puissants de la prière et du jeûne, Derek Prince Ministries, Charlotte.

Ramasamy, A.J., 2004, 'A radical Evangelical-Pentecostal response to the African Renaissance in terms of selected Christian values', master's thesis, UNISA, Pretoria.
Smith, M.E., 1981, 'Can moral and religious conversions be separated?', Thought: A review of Culture and Idea 56(221), 178-184. http://dx.doi.org/10.5840/ thought198156214

Teffo, L., 1999, 'Moral renewal and African experience(s)', in M.W. Makgoba (ed.), African Renaissance: The new struggle, pp. 149-169, Mafube \& Tafelberg, Cape Town.

Van Rensburg, G., 2007, The leadership challenge in Africa: A framework for African Renaissance leaders, Van Schaik Publishers, Pretoria.

Wellman, W., Perkins, G. \& Wellman, N., 2009, 'Educational leadership: The relationship between spirituality and leadership practices', Spirituality in Higher
Education Newsletter 7, 1-6. 